\title{
Communication/Comunicação
}

\section{In vitro antifungal activity of fatty acid methyl esters of the seeds of Annona cornifolia A.St.-Hil. (Annonaceae) against pathogenic fungus Paracoccidioides brasiliensis}

\author{
Atividade antifúngica in vitro dos ésteres metílicos de ácidos graxos das sementes de Annona \\ cornifolia A.St.-Hil. (Annonaceae) sobre o fungo patogênico Paracoccidioides brasiliensis
}

\section{Luciana Alves Rodrigues dos Santos Lima ${ }^{1}$, Susana Johann², Patrícia Silva Cisalpino², Lúcia Pinheiro Santos Pimenta $^{3}$ and Maria Amélia Diamantino Boaventura ${ }^{3}$}

\begin{abstract}
Introduction: Fatty acids are abundant in vegetable oils. They are known to have antibacterial and antifungal properties. Methods: Antifungal susceptibility was evaluated by broth microdilution assay following CLSI (formerly the NCCLS) guidelines against 16 fungal strains of clinical interest. Results: In this work, fatty acid methyl esters (FAME) was able to inhibit 12 clinical strains of the pathogenic fungus Paracoccidioides brasiliensis and were also active in the bioautographic assay against Cladosporium sphaerospermum. Conclusions: FAME was a more potent antifungal than trimethoprim-sulfamethoxazole against $P$. brasiliensis under the experimental conditions tested.
\end{abstract}

Keywords: Fatty acid methyl esters. Antifungal activity. Paracoccidioides brasiliensis.

\section{RESUMO}

Introdução: Os ácidos graxos são abundantes em óleos vegetais. Eles são conhecidos por suas propriedades antibacterianas e antifúngicas. Métodos: A suscetibilidade a antifúngicos foi avaliada pelo ensaio de microdiluição em caldo de acordo com CLSI (anteriormente NCCLS) sobre 16 isolados de interesse clínico. Resultados: Nesse trabalho, os ésteres metílicos de ácidos graxos (FAME) inibiram doze isolados clínicos do fungo patogênico Paracoccidioides brasiliensis, e também foi muito ativo no ensaio de bioautografia sobre o fungo Cladosporium sphaerospermum. Conclusões: FAME foi um antifúngico mais potente do que sulfametoxazol-trimetoprim contra P. brasiliensis, nas condições utilizadas no presente trabalho.

Palavras-chaves: Ésteres metílicos de ácidos graxos. Atividade antifúngica. Paracoccidioides brasiliensis.

Fungal infections have increased significantly, contributing to the cause of morbidity and mortality. The increase in antimicrobial resistance and populations of patients at risk, in conjunction with the restricted number of commercially available antifungal drugs that still present many side effects, are the cause for this problem ${ }^{1}$. These limitations emphasize the need to develop new and more effective antifungal agents. Natural products are attractive prototypes

1. Campus Centro-Oeste Dona Lindu, Universidade Federal de São João Del-Rei, Divinópolis, MG. 2. Departamento de Microbiologia, Universidade Federal de Minas Gerais, Belo Horizonte, MG. 3. Departamento de Química, Universidade Federal de Minas Gerais, Belo Horizonte, MG.

Address to: Dra. Luciana Alves Rodrigues dos Santos Lima. Campus Dona Lindu/ UFSJ. Rua Sebastião Gonçalves Coelho 400, Chanadour, 35501-296 Divinópolis, MG, Brasil.

Phone: 5537 3221-1393; Fax: 5537 3221-1614

e-mail: luarsantos@ufsj.edu.br

Received in 14/10/2010

Accepted in 29/11/2010 for this purpose due to their broad spectrum of biological activities. Although most antibiotics in clinical use have been obtained from microorganisms, a renewed interest in plant antimicrobials has emerged in the last 20 years ${ }^{2}$. The use of extracts or isolation of their compounds is an important tool, especially when the mycosis is difficult to treat, such as paracoccidioidomycosis (PCM). PCM is a systemic endemic disease that affects at least 10 million people in Latin America and it is the 8 th most common cause of death due to chronic/recurrent infections and parasitic diseases in Brazil ${ }^{3}$.

Fatty acids are widely distributed in vegetable oils and they play an important role as nutritious substances and metabolites in living organisms. Many fatty acids are known to have antibacterial and antifungal properties ${ }^{4}$. However, little is known regarding the antifungal property of $A$. cornifolia. In this paper, our group presents data on the fatty acid methyl esters (FAME) of A. cornifolia seeds and their antifungal activity.

Fruits of Annona cornifolia A. St. -Hil. were collected in the town of Curvelo, State of Minas Gerais, Brazil, from January to March 1998. The species was identified by Dr. R. Mello-Silva and a voucher specimen (BHCB 68114) was deposited at the Herbarium of the Institute of Biological Sciences of the Federal University of Minas Gerais (Instituto de Ciências Biológicas, Universidade Federal de Minas Gerais, ICB-UFMG), Belo Horizonte, MG, Brazil. The fruits were open, the seeds removed, washed, dried at $40^{\circ} \mathrm{C}$, powdered (850g) and extracted exhaustively with hexane to achieve extract F01 (79.5g), which was then fractionated by column chromatography on silica gel using gradient systems of n-hexane/dichloromethane/ ethyl acetate/methanol in increasing polarities; a fraction rich in fatty acids (F01-1, 53.2g) was isolated. Part of this fraction (500mg) was refluxed with $1.0 \mathrm{~mol} / 1$ methanolic sodium hydroxide solution for $30 \mathrm{~min}$ and then extracted with ethyl ether. The aqueous phase was acidified with $1.0 \mathrm{~mol} / 1$ hydrochloric acid solution, extracted with ethyl ether. The organic phase was dissolved in hexane and then refluxed with $2 \%$ sulfuric acid methanolic solution $\mathrm{v} / \mathrm{v}$ for $1 \mathrm{~h}$. The fraction rich in fatty acid methyl esters (FAME, 370mg) was obtained after extraction and solvent elimination.

Cladosporium sphaerospermum CCT 1740 was used in the bioautographic assay, which was performed using the procedure described by Homans and Fuchs ${ }^{5}$.

Sixteen fungi strains, which included Paracoccidioides brasiliensis strains, Pb-01 (ATCC-MYA-826), Pb-18 (Fungi Collection of the 
São Paulo University School of Medicine, São Paulo, SP, Brazil), $\mathrm{Pb}-\mathrm{B} 339$ (ATCC 32069), Pb-14 (clinical isolate from acute PCM, São Paulo, Brazil), $\mathrm{Pb}-3$ and $\mathrm{Pb}-4$ (clinic isolates from chronic PCM, São Paulo, Brazil-MHH Forjaz/TIE Svidzinski), Pb-2 (Epm 60), $\mathrm{Pb}-1578, \mathrm{~Pb}-\mathrm{ED} 01, \mathrm{~Pb}-11, \mathrm{~Pb}-9673$ (clinic isolates from acute PCM, Paraná, Brazil, TIE Svidzinski) were used in the biological assays. Candida albicans ATCC 18804, C. tropicalis ATCC 750, C. parapsilosis ATCC 22019 and Cryptococcus gattii ATCC 32608 were used in the biological assays. The strains of $P$. brasiliensis were maintained by continuous passages in YPD (yeast, peptone and dextrose) medium at $37^{\circ} \mathrm{C}$. The fungi were used after 7-10 days of growth. The species of Candida and Cryptococcus were maintained on Sabouraud dextrose agar (Oxoid, Basingstoke, UK) at $4^{\circ} \mathrm{C}$ and transfers were performed at three-month intervals.

Suspensions from the cultures of the P. brasiliensis, Candida spp. and C. gattii were prepared according to both the CLSI M27-A2 document (formerly the NCCLS) ${ }^{6}$ and modification suggested by Johann et $\mathrm{al}^{7}$ to obtain a final suitable inoculum dilution for each strain. For P. brasiliensis, yeast cells in the exponential phase were collected aseptically with a platinum loop and resuspended in a tube containing $5 \mathrm{ml}$ of sterile saline. When large aggregates existed, they were allowed to settle for several minutes and the supernatants were collected. The transmittance of the suspension was measured at a wavelength of $530 \mathrm{~nm}$ after homogenization by vortexing and adjusted to $70 \%$. A 0.1-ml aliquot of this suspension was then added to $0.9-\mathrm{ml}$ of RPMI medium (Sigma, St. Louis, MO, USA). The fungal cultures of $P$. brasiliensis had a final inoculum of $10^{4}$ cells $/ \mathrm{ml}$, and the Candida spp. and C. gattii cultures had a final inoculum of $1.5+1.0 \times 10^{3}$ cells $/ \mathrm{ml}$ (formerly the NCCLS) ${ }^{6}$.

The minimal inhibitory concentrations (MIC) was obtained for broth microdilution testing performed in accordance with the guidelines described in the CLSI M27-A2 document (formerly the NCCLS $)^{6}$ and the assays with P. brasiliensis were performed in accordance with Johann et $\mathrm{al}^{7}$. Amphotericin B (Sigma, St Louis, USA) and trimethoprim-sulfamethoxazole (80mg/400mg) (Ducto, Goias, Brazil) were included as positive antifungal control, using stock solutions prepared in dimethysulfoxide and water, respectively. RPMI medium (Sigma, St. Louis, MO, USA) was used without compounds or solvents as a control for growth and sterility. Solvent DMSO at the same volumes used in the assay was used as control for toxicity. After inoculation of Candida spp. and C. gattii plates were incubated at $37^{\circ} \mathrm{C}$ for $48 \mathrm{~h}$ for Candida spp. and $72 \mathrm{~h}$ for C. gattii. For $P$. brasiliensis strains, the plates were incubated at $37^{\circ} \mathrm{C}$ for 10 days. The endpoints were determined visually by comparison with the drug-free growth control well. The MIC values were expressed in $\mu \mathrm{g} / \mathrm{ml}$ and correspond to the lowest concentrations that did not permit detection of any visual fungal growth.

The minimal fungicidal concentration (MFC) values for pure compounds were determined as follows: from the microtiter plate used to determine the MIC values, the test wells that showed a) complete fungal growth inhibition (clear wells), b) growth similar to that of the no-drug control well, and c) growth control wells. The in vitro MFC of each compound tested was determined by streaking $10 \mu \mathrm{l}$ from each well that showed complete inhibition (100\% inhibition or a clear well) and from the growth control well onto YPD plates for P. brasiliensis and Sabouraud dextrose agar (Oxoid, Basingstoke, UK) for Candida spp. and C. gattii. The plates were incubated at $37^{\circ} \mathrm{C}$ for 10 days for P. brasiliensis and 48 and $72 \mathrm{~h}$ at $37^{\circ} \mathrm{C}$ for Candida spp. and C. gattii, respectively. The MFC was determined as the lowest drug concentration at which fewer than three colonies were able to grow ${ }^{8}$.

To explore the possibility of assessment of drug interactions, the following processes were performed: eight serial dilutions of FAME $(300-2.34 \mu \mathrm{g} / \mathrm{ml})$ and amphotericin B $(1-0.008 \mu \mathrm{g} / \mathrm{ml})$ were prepared with the same solvents and medium (Synthetic RPMI/Sigma, St. Louis, MO, USA) with L-glutamine buffered to $\mathrm{pH} 7.0$ with 0.165 morpholine propanesulfonic acid (MOPS, Sigma) used in the MIC test. Fifty microliter aliquots of each dilution of FAME were added to the wells of 96-well plates in vertical orientation and 50 microliters of each amphotericin B dilutions were added in horizontal orientation so that the plate contained various concentration combinations of the two compounds (amphotericin B and FAME). A 100 $\mu 1$ suspension of $\mathrm{Pb}-18$, same used in MIC test, was added to each well and cultured for 14 days. The drug combination in which the growth was completely inhibited was taken as effective MIC for the combination. Fractional inhibitory concentration (FIC) of amphotericin B was calculated as the MIC of amphotericin B in the presence of FAME dividided by the MIC of amphotericin B alone. The FIC of FAME was calculated in the same way for amphotericin B. The fractional inhibitory concentration index (FICI) was calculated by adding both FICs and was interpreted as a synergism effect when it was $\leq 0.5$, as additive or no interaction when it was $\leq 0.5$ to 2.0 and as antagonistic when it was $>2.0$. This experiment was also performed to determine the effect of the combination FAME with trimethoprim-sulfamethoxazole (dilutions 600-4.6 $\mathrm{g} / \mathrm{ml})^{9}$.

Gas chromatography analysis of the fraction rich in methyl esters from seeds of Annona cornifolia revealed a higher percentage of unsaturated fatty acids (71.4\%). Among the latter, oleic acid (51.5\%) and linoleic acid (19.1\%) showed the highest quantities. Among the saturated fatty acids, palmitic acid was the most abundant (16.9\%), followed by stearic acid (5.6\%) (Table $\mathbf{1})$.

TABLE 1 - Fatty acid composition and percentages of oils from the fraction rich in methyl esters of Annona cornifolia.

\begin{tabular}{lcc}
\hline Peak $(\mathrm{n})$ & Fatty acids in methyl esters form & Relative percentage \\
\hline 1 & methyl myristate & 0.2 \\
\hline 2 & methyl palmitate & 16.9 \\
\hline 4 & methyl stearate & 5.6 \\
\hline 5 & methyl oleate & 51.5 \\
\hline 6 & methyl linoleate & 19.1 \\
\hline Total & methyl linolenate & 0.8 \\
\hline
\end{tabular}

FAME: fatty acid methyl esters

The antifungal activity ofFAME obtained from the seeds of Annona cornifolia was evaluated against 12 clinical isolates of $P$. brasiliensis, C. albicans, C. tropicalis, C. parapsilosis and C. gattii. Analysis of the results showed that C. albicans, C. tropicalis, C. parapsilosis and C. gattii strains were not affected by FAME (Table 2). For C. sphaerospermum, the MIC value was $12.5 \mu \mathrm{g} / \mathrm{ml}$. P. brasiliensis isolates were more susceptible to FAME than trimethoprim-sulfamethoxazole, with $\mathrm{MIC}$ values that varied from 3.4 to $55.5 \mu \mathrm{g} / \mathrm{ml}$. The isolates $\mathrm{Pb}-2, \mathrm{~Pb}-8$ and $\mathrm{Pb}-\mathrm{B} 339$ were more sensitive to FAME compared with other isolates of $P$. brasiliensis (MIC 3.4, 6.9 and $6.9 \mu \mathrm{g} / \mathrm{ml}$, respectively). $\mathrm{Pb}-01$ was the most resistant isolate to FAME $(55.5 \mu \mathrm{g} / \mathrm{ml})$. $\mathrm{Pb}-18$ and $\mathrm{Pb}-18$ virulent showed the same results for the MIC test, 
TABLE 2 - Minimal inhibitory concentration and minimal fungicidal concentration of FAME from Annona cornifolia against 16 clinical important fungi.

\begin{tabular}{|c|c|c|c|c|c|c|}
\hline \multirow[b]{2}{*}{ Fungi } & \multicolumn{2}{|c|}{ FAME } & \multicolumn{2}{|c|}{ Amphotericin B } & \multicolumn{2}{|c|}{ Trimethoprim-sulfamethoxazole } \\
\hline & $\begin{array}{c}\text { MIC } \\
(\mu \mathrm{g} / \mathrm{ml})\end{array}$ & $\begin{array}{c}\text { MFC } \\
(\mu \mathrm{g} / \mathrm{ml})\end{array}$ & $\begin{array}{c}\text { MIC } \\
(\mu \mathrm{g} / \mathrm{ml})\end{array}$ & $\begin{array}{c}\text { MFC } \\
(\mu \mathrm{g} / \mathrm{ml})\end{array}$ & $\begin{array}{c}\text { MIC } \\
(\mu \mathrm{g} / \mathrm{ml})\end{array}$ & $\begin{array}{c}\text { MFC } \\
(\mu \mathrm{g} / \mathrm{ml})\end{array}$ \\
\hline Candida albicans & $\geq 500$ & - & 1.0 & 1.0 & - & - \\
\hline Candida tropicalis & $\geq 500$ & - & 0.25 & 0.25 & - & - \\
\hline Candida parapsilosis & $\geq 500$ & - & 0.5 & 0.5 & - & - \\
\hline Cryptococcus gattii & $\geq 500$ & - & 1.2 & 1.2 & - & - \\
\hline Paracoccidioides brasiliensis $\mathrm{Pb}-18$ & 27.7 & 27.7 & 0.250 & 0.250 & 300 & 300 \\
\hline Paracoccidioides brasiliensis ED01 & 13.8 & 13.8 & 0.031 & 0.031 & 75 & 75 \\
\hline Paracoccidioides brasiliensis 2 & 3.4 & 3.4 & 0.031 & 0.031 & 150 & 150 \\
\hline Paracoccidioides brasiliensis 11 & 13.8 & 13.8 & 0.031 & 0.031 & 150 & 150 \\
\hline Paracoccidioides brasiliensis $\mathrm{Pb}-01$ & 55.5 & 55.5 & 0.125 & 0.125 & 300 & 300 \\
\hline Paracoccidioides brasiliensis B339 & 6.9 & 6.9 & 0.062 & 0.062 & 75 & 75 \\
\hline Paracoccidioides brasiliensis 3 & 13.8 & 13.8 & 0.015 & 0.015 & 300 & 300 \\
\hline Paracoccidioides brasiliensis 14 & 27.7 & 27.7 & 0.125 & 0.125 & 75 & 75 \\
\hline Paracoccidioides brasiliensis 8 & 6.9 & 6.9 & 0.062 & 0.062 & 300 & 300 \\
\hline Paracoccidioides brasiliensis 1578 & 13.8 & 13.8 & 0.062 & 0.062 & 75 & 75 \\
\hline Paracoccidioides brasiliensis 4 & 27.7 & 27.7 & 0.062 & 0.062 & 150 & 150 \\
\hline Paracoccidioides brasiliensis $\mathrm{Pb}-18$ virulent & at 27.7 & 27.7 & 0.062 & 0.062 & 300 & 300 \\
\hline
\end{tabular}

FAME: fatty acid methyl esters, MIC: minimal inhibitory concentration, MFC: minimal fungicidal concentration.

showing that FAME presents activity against virulent isolates. FAME showed MFC results equivalent to MIC results (Table 2). Activity against $P$. brasiliensis and not Candida spp. and Cryptococcus could be explain by the fact that Candida (Saccharomycetales), Cryptococcus (Tremelalles) and P. brasiliensis (Onygenalles) are phylogenetically quite distant, presenting many morphological and physiological differences. The specific activity against $P$. brasiliensis also suggests the selectivity of natural products.

Few works reporting the biological activity of natural products against the pathogenic fungus $P$. brasiliensis were available in the literature. The natural product $(R)$-goniothalamin and its synthetic enantiomer were evaluated against a panel of microorganisms that included three strains of $P$. brasiliensis ( $\mathrm{Pb}-01, \mathrm{~Pb}-18$, and $\mathrm{Pb}-\mathrm{B} 339$ ). Their MIC values ranged between 7 and $22 \mu \mathrm{g} / \mathrm{ml}$ on P. brasiliensis ${ }^{10}$. In this study, FAME from A. cornifolia showed activity similar to enantiomers goniothalamin against $P$. brasiliensis isolates. In another experiment, Campos et $\mathrm{al}^{11}$ tested the in vitro susceptibility of 11 clinical P. brasiliensis isolates to trichothecenes from Fusarium sp. The results of the study show that all the isolates were susceptible to T2-toxin and a mixture of 8-n-butyryl-neosolaniol and 8-isobutyryl-neosolaniol.

Silva et a ${ }^{12}$ verified the susceptibilities of virulent $P$. brasiliensis ( $\mathrm{Pb}-18$ ) for amphotericin $\mathrm{B}$, fluconazole, itraconazole, sulfamethoxazole and ketoconazole. The MIC value for amphotericin B was higher $(0.5 \mu \mathrm{g} / \mathrm{ml})$ than that determined in the present work $(0.062 \mu \mathrm{g} / \mathrm{ml})$ for virulent $\mathrm{Pb}-18$. However, the value observed for the nonvirulent $\mathrm{Pb}-18$ strain $(0.25 \mu \mathrm{g} / \mathrm{ml})$ was much closer to the value obtained by Silva et $\mathrm{al}^{12}$. Nakai et $\mathrm{al}^{13}$ also tested amphotericin $\mathrm{B}$ against seven isolates of $P$. brasiliensis and the MIC values ranged between 0.0078 and $0.25 \mu \mathrm{g} / \mathrm{ml}$, while in the present work, results for MIC values ranged between 0.015 and $0.25 \mu \mathrm{g} / \mathrm{ml}$. This can be explained by the fact that different isolates of $P$. brasiliensis were used.

For sulfamethoxazole, Silva et a ${ }^{12}$ showed a MIC value of $300 \mu \mathrm{g} /$ $\mathrm{ml}$. Despite the obtaining equivalent results in the present work $(300 \mu \mathrm{g} / \mathrm{ml})$, comparison was not possible because our group used sulfamethoxazole combined with trimethoprim and a different culture medium. Using MVM medium, Stevens \& Phuoc ${ }^{14}$ determined MIC values for sulfamethoxazole-trimethoprim (5:1) that were lower than that determined in the present work using RPMI medium. In another study ${ }^{15}$ involving determination of MIC for sulfamethoxazoletrimethoprim (5:1) using the MVM medium, the values obtained were very similar with those reported in the present work $(320 \mu \mathrm{g} / \mathrm{ml})$. Stevens \& Phuoc ${ }^{14}$ used four different isolates of $P$. brasiliensis and observed great variation in the MIC values (ranging between 0.9 and $46.9 \mu \mathrm{g} / \mathrm{ml}$ ) for sulfamethoxazole-trimethoprim (5:1). Stevens \& Phuoc $^{14}$ also observed variation among the isolates treated only with sulfamethoxazole, with MIC values of $0.97 \mu \mathrm{g} / \mathrm{ml}$ for isolate 262 and $\geq 2.000 \mu \mathrm{g} / \mathrm{ml}$ for isolates 268,263 and 264 . These results show that great variation occurs among different isolates of $P$. brasiliensis. The $P$. brasiliensis isolates used by Stevens \& Phuoc ${ }^{14}$ were different from the isolates used in the present work and this could explain the differences observed in the MIC values between these studies. In addition the authors cited above used only a few isolates of $P$. brasiliensis.

To explore the possibility of developing a more powerful combination therapy of FAME with amphotericin B and with trimethoprim-sulfamethoxazole, the checkerboard microtiter test was performed with combined samples. Table 3 demonstrates the occurrence of an additive effect of FAME with amphotericin B. This

TABLE 3 - Fractional inhibiting concentration and fractional inhibitory concentration index of fatty acid methyl esters from Annona cornifolia against Paracoccidioides brasiliensis isolate $\mathrm{Pb}-18$.

\begin{tabular}{lccc}
\hline Compounds & $\begin{array}{c}\text { MIC in combination } \\
(\mu \mathrm{g} / \mathrm{ml})\end{array}$ & FIC & FICI \\
\hline 1. FAME & 27.7 & 1 & 1.5 \\
\hline 2. Amphotericin B & 0.125 & 0.5 & \\
\hline 1. FAME & 0.86 & 0.03 & 2.03 \\
\hline 2. Trimethoprim-sulfamethoxazole & 600 & 2 & \\
\hline
\end{tabular}

MIC: minimal inhibitory concentration, FIC: fractional inhibiting concentration, FICI: fractional inhibitory concentration index, FAME: fatty acid methyl esters. 
is an important observation, as amphotericin B is known for its significant nephrotoxicity, indicating that following further assays with FAME, this drug could be used in combination in order to reduce the amount of amphotericin $\mathrm{B}$ administered.

Many natural products are useful as drugs or as biochemical tools to investigate disease processes. The FAME obtained from Annona cornifolia were tested for the first time against the pathogenic fungus P. brasiliensis. The results showed that this compound is active against several clinical strains of this fungus and opens the possibility for discovery of new compounds to treat paracoccidioidomycosis.

\section{ACKNOWLEDGMENTS}

The authors are grateful to Dr. R. Mello-Silva for his assist in plant identification.

\section{CONFLICT OF INTEREST}

The authors declare that there are no conflicts of interest.

\section{FINANCIAL SUPPORT}

The Conselho Nacional de Desenvolvimento Científico e Tecnológico (CNPq) and the Coordenação de Aperfeiçoamento de Pessoal de Nível Superior (CAPES) supported this work.

\section{REFERENCES}

1. Ghannoum MA, Rice LB. Antifungal agents: mode of action, mechanism of resistance, and correlation of these mechanisms with bacterial resistance. Clin Microbiol Rev 1999; 12:501-517.

2. Duarte MCT, Figueira GM, Sartoratto A, Rehder VLG, Delarmelina C. Anti-Candida activity of Brazilian medicinal plants. J Ethnopharmacol 2005; 97:305-311.

3. Marini MM, Zanforlin T, Santos PC, Barros RRM, Guerra ACPR, Felipe MSS et al. Identification and characterization of Tc1/mariner-like DNA transposons in genomes of the pathogenic fungi of the Paracoccidioides species complex. BMC Genomics 2010; 11:130-149.

4. Cakir A. Essential oil and fatty acid composition of the fruits of Hippophae rhamnoides L. (Sea Buckthorn) and Myrtus communis L. from Turkey. Biochem Syst Ecol 2004; 32:809-816.

5. Homans AL, Fuchs A. Direct bioautography on thin-layer chromatograms as a method for detecting fungitoxic substances. J Chromatogr 1970; 51:327-331.

6. National Committee for Clinical Laboratory Standards. Method for Broth Dilution Antifungal Susceptibility Testing of Yeast. $2^{\text {nd }}$ ed. Wayne (PA). USA: NCCLS; 2002.

7. Johann S, Cisalpino PS, Watanabe GA, Cota BB, Siqueira EP, Pizzolatti MG, et al. Antifungal activity of extracts of some plants used in the Brazilian traditional medicine against the pathogenic fungus Paracoccidioides brasiliensis. Pharmac Biol 2010; 48:388-396.

8. Espinel-Ingroff A, Boyle K, Sheehan DJ. In vitro antifungal activities of voriconazole and reference agents as determined by NCCLS methods: Review of the literature. Mycopathologia 2001; 150:101-115.

9. White RL, Burgess DS, Mandururu M, Bosso JA. Comparison of three different in vitro methds of detecting synergy: time kill, checkboard, and E-test. Antimicrob Agents Chemother 1996; 40:1914-1918.

10. Martins CVB, Resende MA, Magalhães TFF. Antifungal activity of goniothalamin enantiomers. Lett Drug Des Discov 2008; 5:74-78.

11. Campos FF, Johann S, Cota BB, Alves TMA, Rosa LH, Caligiorne RB, et al. Antifungal activity of trichothecenes from Fusarium sp. against clinical isolates of Paracoccidioides brasiliensis. Mycoses 2010; 53:1-6.
12. Silva MB, Marques AF, NosanchukJD, Casadevall A, Travassos LR, Taborda CP. Melanin in the dimorphic fungal pathogen Paracoccidioides brasiliensis: effects on phagocytosis, intracellular resistance and drug susceptibility. Microbes Infect $2006 ; 8: 197-205$

13. Nakai T, Uno J, Ikeda F, Jauregui A. In vitro antifungal activity of micafungin (FK463) against dimorphic fungi: comparison of yeast-like and mycelial forms. Antimicrob Agents Chemother 2003; 47:1376-1381.

14. Stevens DA, Phuoc TVO. Synergistic interaction of trimethoprim and sulfamethoxazole on Paracoccidioides brasiliensis. Antimicrob Agents Chemother 1982; 21:852.

15. Hahn RC, Morato CYT, Santos NL, Ferreira JF, Hamdan JS. Disseminated paracoccidioidomycosis: correlation between clinical and in vitro resistance to ketoconazole and trimethoprim-sulphamethoxazole. Mycoses 2003; 46:342-347. 